\title{
Solid Phase Extraction of Cu(II) as Diethyldithiocarbamate (DDTC) Complex by Polyurethane Foam
}

\author{
Otoniel D. Sant'Ana ${ }^{a}$, Luciene S. Jesuino ${ }^{a}$, Ricardo J. Cassella ${ }^{b, \#, ~ M a r c e l o ~ S . ~ C a r v a l h o ~}{ }^{c}$ and \\ Ricardo E. Santelli ${ }^{*, a}$ \\ ${ }^{a}$ Departamento de Geoquímica, Universidade Federal Fluminense, Outeiro de São João Batista s/n, Centro, \\ 24020-007 Niterói - RJ, Brazil \\ ${ }^{b}$ Centro Federal de Educação Tecnológica de Química-RJ, Rua Senador Furtado 121-125, Maracanã, \\ 20270-021 Rio de Janeiro - RJ, Brazil \\ ${ }^{c}$ Instituto de Engenharia Nuclear - CNEN, CP 68550, 21945-590 Rio de Janeiro - RJ, Brazil
}

\begin{abstract}
Neste trabalho é apresentado um estudo referente à sorção do complexo cobre-dietilditiocarbamato, empregando espuma de poliuretano (EPU) como fase sólida. Foi observado que em pH 6,8 e na presença de DDTC 4,5 x 10-5 $\mathrm{mol} \mathrm{L}^{-1}$ a sorção de $\mathrm{Cu}(\mathrm{II})\left(80\right.$ ou $\left.150 \mu \mathrm{g} \mathrm{L}^{-1}\right)$ foi máxima. O tempo requerido para que o equilíbrio fosse alcançado foi de $40 \mathrm{~min}$. A partir dos dados deste experimento foi realizada uma caracterização cinética através da aplicação de três modelos, que revelaram que a difusão do complexo na interface entre sólido-líquido foi a etapa determinante na velocidade do processo sortivo. Pôde-se também afirmar que a sorção do complexo se dá através de um mecanismo similar aquele observado em extração líquido-líquido, usando éter como solvente. Testes com possíveis interferentes demonstraram a relativa seletividade da extração do complexo metálico, que pode ser melhorada com a presença de um agente mascarante adequado.
\end{abstract}

This paper presents a study about the sorption of copper-diethyldithiocarbamate complex onto polyurethane foam (PUF). It was observed that the maximum sorption of $\mathrm{Cu}$ (II) $\left(80\right.$ or $\left.150 \mu \mathrm{g} \mathrm{L}^{-1}\right)$ was verified at $\mathrm{pH} 6.8$ in presence of $4.5 \times 10^{-5} \mathrm{~mol} \mathrm{~L}^{-1}$ DDTC. The shaking time needed to achieve the equilibrium was 40 minutes. From these data, a kinetic characterization was performed by applying three models, which revealed that a film diffusion process was a rate-determining mechanism. Results also indicated that a ether-like solvent extraction was the sorption mechanism. The investigation of many metallic ions as concomitants showed that the sorption by foam is relatively selective and it can be enhanced by using a suitable masking agent or incrementing the foam mass.

Keywords: solid phase extraction, polyurethane foam, diethyldithiocarbamate, copper

\section{Introduction}

Nowadays, the removal of toxic substances from aqueous medium such as effluents is of great interest for environmental and human health purposes. For this reason, the control and treatment of these effluents have become one of the most important steps of the productive process. In this scenario, the application of solid phase extraction (SPE) procedures has increased in last few years, specially due to its efficiency and low requirements in terms of cost. ${ }^{1}$

Among several other solid phases employed in SPE

\footnotetext{
* e-mail: santelli@geoq.uff.br

* Present address: Departamento de Química Analítica, Universidade Federal Fluminense, Outeiro de São João Batista s/n, Centro, 24020-007, Niterói - RJ, Brazil.
}

methodologies, ${ }^{2-5}$ the use of polyurethane foams (PUF) has grown up since publication of the pioneer work of Bowen. ${ }^{6}$ Various research papers were published describing the use of unloaded foams for analytical preconcentration and separation of organic and inorganic species in aqueous medium. ${ }^{7-11}$ Additionally, the polyurethane foams have been used as solid supports for specific reagents ${ }^{12-14}$ which, according to the literature, leads to SPE procedures with high selectivity and analytical throughput. ${ }^{15}$ Also, some papers have focused the characterization of the sorption process by studying the kinetics and thermodynamics aspects related to the extraction. ${ }^{16-18}$

It is well known that the reaction between diethyldithiocarbamate (DDTC) and several metal ions yields sparingly water-soluble metal complexes that can be adequately extracted from aqueous medium with a wide 
variety of non-polar organic solvents. The addition of an aqueous solution of sodium-DDTC to a slightly acidic or alkaline solution of $\mathrm{Cu}(\mathrm{II})$ produces a brown colloidal suspension of the $\mathrm{Cu}(\mathrm{II})$-DDTC which can be extracted by chloroform or carbon tetrachloride. This approach is classically employed in the spectrophotometric determination of copper. ${ }^{19}$ Some other works report the use of PUF loaded with DDTC for collection of $\mathrm{Co}(\mathrm{II}), \mathrm{Hg}(\mathrm{II})$ and $\mathrm{Sb}$ (III) from aqueous solution..$^{20-22}$

This study was performed to demonstrate the potential of polyurethane foam in the separation and removal of $\mathrm{Cu}$ (II) from aqueous medium, exploring the high affinity between PUF and the hydrophobic Cu(II)-DDTC complex. Also, this paper presents an detailed investigation about the influence of different kinetic and chemical parameters which control the sorption of $\mathrm{Cu}$ (II)-DDTC complex by PUF. So that, the main goal was to characterize the processes involved in the extraction of $\mathrm{Cu}$ (II)-DDTC complex from solution by the low cost solid PUF.

\section{Experimental}

\section{Apparatus}

The samples copper solutions were analyzed on a Hitachi (Tokyo, Japan) polarized Zeeman atomic absorption spectrometer, model Z-8200, equipped with a copper hollow cathode lamp and an autosampler Hitachi model SSC-300. Integrated absorbance measurements were carried out, using Hitachi Pyro tube-type cuvette. The instrumental operating conditions and the temperature program set are summarized in Tables 1 and 2, respectively.

\section{Reagents}

All reagents were of analytical grade and used without further purification. The solutions were always prepared with water purified in a Simplicity Milli-Q System (Millipore, Bedford, MA, USA).

A $1000 \mathrm{mg} \mathrm{L}^{-1}$ copper stock solution was prepared by dissolving $1 \mathrm{~g}$ of metallic copper (Merck, Darmstadt, Germany) in a heated mixture of $15 \mathrm{~mL}$ of concentrated $\mathrm{HNO}_{3}$ (Merck, Darmstadt, Germany) and $50 \mathrm{~mL}$ of water. After cooling, the volume was made up to $1000 \mathrm{~mL}$ in a volumetric flask.

A $0.1 \%\left(4.4 \times 10^{-3} \mathrm{~mol} \mathrm{~L}^{-1}\right)$ DDTC stock solution was prepared by dissolving $0.1 \mathrm{~g}$ sodium diethyldithiocarbamate reagent in approximately $80 \mathrm{~mL}$ heated $\left(60^{\circ} \mathrm{C}\right)$ water. Afterwards, the volume was made up to $100 \mathrm{~mL}$ in a volumetric flask. This solution was stable for two weeks, at least.
A $0.5 \mathrm{~mol} \mathrm{~L}^{-1}$ acetic buffer solutions with $\mathrm{pH} 4.0,5.0$ and 6.0 were prepared by dissolving enough amounts of sodium acetate (Vetec, Rio de Janeiro, Brazil) and glacial acetic acid (Merck, Darmstadt, Germany) and $0.1 \mathrm{~mol} \mathrm{~L}^{-1}$ $\mathrm{NaOH}$ (Merck, Darmstadt, Germany) or $0.1 \mathrm{~mol} \mathrm{~L}^{-1} \mathrm{HCl}$ (Merck, Darmstadt, Germany) were added until to attain the desirable $\mathrm{pH}$. Then, the volume was made up to $1000 \mathrm{~mL}$.

A $0.5 \mathrm{~mol} \mathrm{~L}^{-1}$ total concentration phosphate buffer solution with $\mathrm{pH} 6.8$ was prepared by dissolving an enough amount of di-potassium hydrogen phosphate trihydrate (Merck, Darmstadt, Germany) and potassium di-hydrogen phosphate (Merck, Rio de Janeiro, Brazil) in water to complete $1000 \mathrm{~mL}$ just after to adjust the $\mathrm{pH}$ to 6.8 with $0.1 \mathrm{~mol} \mathrm{~L}^{-1} \mathrm{NaOH}$.

A $0.5 \mathrm{~mol} \mathrm{~L}^{-1}$ borate buffer solutions with $\mathrm{pH} 9.0$ and 10 were prepared by dissolving an enough amount of boric acid (Merck, Rio de Janeiro, Brazil) in water sufficient to complete $1000 \mathrm{~mL}$. Before volume adjustment, the $\mathrm{pH}$ solutions were settled to 9.0 and 10 with $0.1 \mathrm{~mol} \mathrm{~L}^{-1} \mathrm{NaOH}$ or $0.1 \mathrm{~mol} \mathrm{~L}^{-1} \mathrm{HCl}$.

The Triton X-100 used was supplied by Vetec (Rio de Janeiro, Brazil).

A commercial open cell, polyether-type PUF (Vulcan do Brasil - VCON 202, 42 \% resilience and 10-12 cells per linear $\mathrm{cm}$ ) was pulverized in a blender and used as previously described. ${ }^{11}$

Table 1. Operational conditions employed in the determination of $\mathrm{Cu}$ by ETAAS

\begin{tabular}{ll}
\hline Parameter & Set Value \\
\hline Lamp current & $7.5 \mathrm{~mA}$ \\
Wavelenght & $324.8 \mathrm{~nm}$ \\
Spectral bandwidth & $1.30 \mathrm{~nm}$ \\
Purge gas & Argon \\
Background correction mode & Polarized Zeeman \\
Graphite furnace & Pyrolytical coated tube-type \\
\hline
\end{tabular}

Table 2. Temperature Program employed in the determination of $\mathrm{Cu}$ by ETAAS

\begin{tabular}{lccc}
\hline $\begin{array}{l}\text { Temperature } \\
\text { Stage }\end{array}$ & $\begin{array}{c}\text { Temperature } \\
\left({ }^{\circ} \mathrm{C}\right)\end{array}$ & $\begin{array}{c}\text { Time } \\
(\mathrm{s})\end{array}$ & $\begin{array}{c}\text { Ar flow rate } \\
\left(\mathrm{mL} \mathrm{min}{ }^{-1}\right)\end{array}$ \\
\hline Dry & $80-90$ & 20 & 200 \\
Dry & $90-100$ & 20 & 200 \\
Dry & $100-120$ & 20 & 200 \\
Dry & $120-140$ & 10 & 200 \\
Pyrolysis $^{\mathrm{a}}$ & 600 & 30 & 200 \\
Atomization $^{\mathrm{a}}$ & 2500 & 10 & 0 \\
Clean & 2550 & 4 & 200 \\
\hline
\end{tabular}

${ }^{a}$ Optimized from pyrolysis and atomization curves. 


\section{General procedure}

Extraction experiments were carried out by agitating $25 \mathrm{~mL}$ of a solution containing known concentrations of $\mathrm{Cu}$ (II) $\left(80 \mu \mathrm{g} \mathrm{L}^{-1}\right)$ and DDTC $\left(4.5 \times 10^{-5} \mathrm{~mol} \mathrm{~L}^{-1}\right)$ with 10 $\mathrm{mg}$ of PUF during $1 \mathrm{~h}$, using a mechanical shaker. The $\mathrm{pH}$ of the solution was maintained in 6.8 by employing a phosphate buffer solution. All these parameters were kept constant in all experiments except otherwise mentioned.

After passed the enough time to the system attain the equilibrium, the mixture was filtered (polyethylene filtration unit with $0.45 \mu \mathrm{m}$ pore size and $13 \mathrm{~mm}$ outer diameter, Millipore, Bedford, MA, USA) and the concentration of copper in the remained solution was determined by electrothermal atomic absorption spectrometry (ETAAS). The percentage of $\mathrm{Cu}$ (II)-DDTC complex sorbed by foam was calculated from these data using the following equation:

$$
\mathrm{Cu}_{\text {sorbed }}(\%)=\frac{\mathrm{C}_{0}-\mathrm{C}_{\mathrm{f}}}{\mathrm{C}_{0}} \times 100
$$

where $\mathrm{C}_{0}$ and $\mathrm{C}_{\mathrm{f}}$ are the concentrations of $\mathrm{Cu}$ (II) before and after to perform the extraction procedure. The percent sorption was the average of three measurements, at least. The measurements precision, in this case, was always around $5 \%$.

\section{Results and Discussion}

\section{Extraction chemical characterization}

The extraction of $\mathrm{Cu}$ (II)-DDTC complex from aqueous solution by PUF is dependent on the $\mathrm{pH}$, since its formation is associated to this parameter. As the complex is a noncharged specie, its sorption by PUF is enhanced due to hydrophobic characteristics of the foam, which can act as a non-polar solvent.

Therefore, experiments were done in order to evaluate the influence of the $\mathrm{pH}$ on the sorption process. For this purpose, a set of tests was carried out by preparing aliquots of $25 \mathrm{~mL}$ of solution containing $1 \mu \mathrm{g} \mathrm{Cu}$ (II) $\left(40 \mu \mathrm{g} \mathrm{L}^{-1}\right)$ and $1.74 \times 10^{-4} \mathrm{~mol} \mathrm{~L}^{-1}$ DDTC and varying the $\mathrm{pH}$ by using different buffer systems, covering the $\mathrm{pH}$ range between 4.0 and 10. The buffer solutions employed were listed above. A PUF mass of $10 \mathrm{mg}$ was added to the same solutions and the system was mixed during one hour. The obtained results (Figure 1) showed that at $\mathrm{pH} 4$ only $51 \%$ of $\mathrm{Cu}$ (II)-DDTC complex is sorbed by PUF. On the other hand, quantitative sorption is observed at $\mathrm{pH}$ higher than 6.0. Based on the results observed, the $\mathrm{pH}$ was buffered with phosphate system at 6.8 .

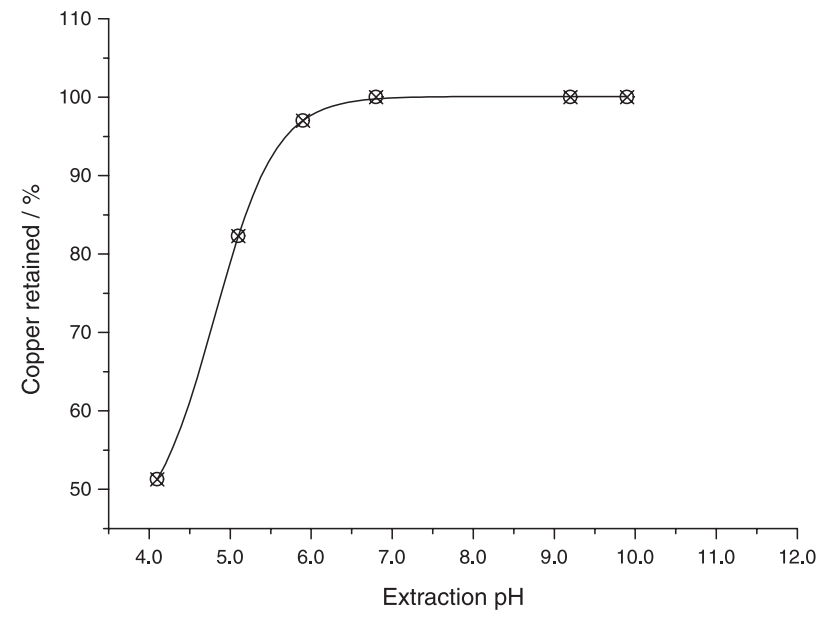

Figure 1. Effect of the $\mathrm{pH}$ on the $\mathrm{Cu}(\mathrm{II})$-DDTC complex sorption. PUF mass $=10 \mathrm{mg} ;[$ DDTC $]=1.74 \times 10^{-4} \mathrm{~mol} \mathrm{~L}^{-1} ;[\mathrm{Cu}(\mathrm{II})]=40 \mu \mathrm{g} \mathrm{L}^{-1}$; Shaking time $=1 \mathrm{~h}$.

Extraction of copper as a DDTC complex is dependent on both complex formation and occurrence of effective shocks between solid (PUF) and analyte present in the aqueous phase. This fact suggests that special attention should be given on a study of optimum ratio between metal and complexing agent concentrations. Thus, this study was carried out fixing both the $\mathrm{Cu}$ (II) concentration and $\mathrm{pH}$ in 6.8, and varying the DDTC concentration in solution from $1.1 \times 10^{-7}$ to $2.2 \times 10^{-4} \mathrm{~mol} \mathrm{~L}^{-1}$. As can be seen in Figure 2, when the DDTC concentrations was $4.5 \times 10^{-5}$ mol L $\mathrm{L}^{-1}$, a quantitative sorption of $\mathrm{Cu}$ (II) was achieved for the two situations tested $\left([\mathrm{Cu}(\mathrm{II})]=80\right.$ and $\left.150 \mu \mathrm{g} \mathrm{L}^{-1}\right)$.

The effect of the extraction volume on the $\mathrm{Cu}(\mathrm{II})$-DDTC sorption was investigated by keeping PUF and $\mathrm{Cu}(\mathrm{II})$ masses (10 mg and $1 \mu \mathrm{g}$, respectively) constants and varying

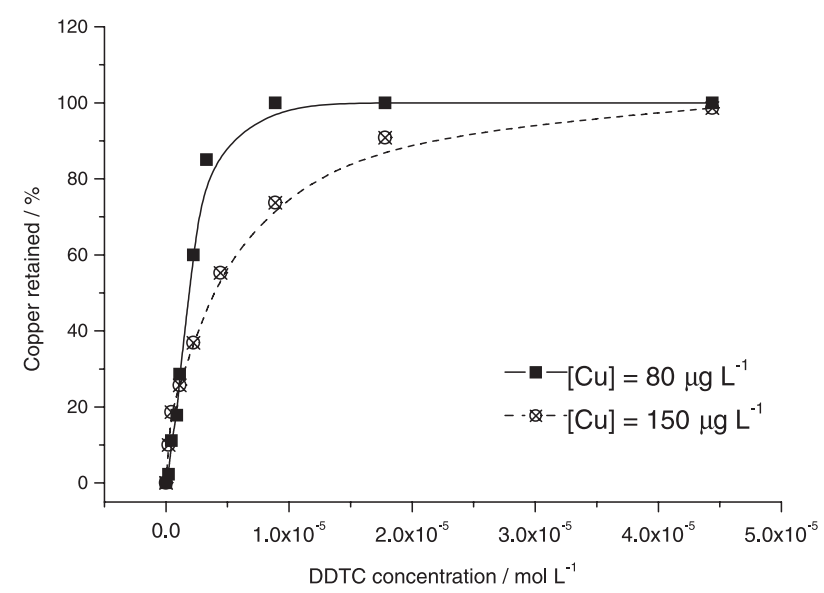

Figure 2. Influence of the DDTC concentration on the $\mathrm{Cu}(\mathrm{II})(80$ and $150 \mu \mathrm{g} \mathrm{L}^{-1}$ ) extraction by PUF. PUF mass $=10 \mathrm{mg} ; \mathrm{pH}=6.8$; Shaking time $=1 \mathrm{~h}$. 
the solution volume. It was verified that increasing the extraction volume, $\mathrm{Cu}$ (II) complex retention is inhibited as consequence of smaller probability of effective shocks occurrence.

In a SPE process based on a reverse-phase mechanism, the addition of a substance that increases the hydrophilic characteristic of the specie to be retained decreases the sorption efficiency. So that, in order to verify this effect on the extraction of $\mathrm{Cu}$ (II)-DDTC by PUF, a set of experiments was carried out by preparing solutions containing $40 \mu \mathrm{g} \mathrm{L}^{-1} \mathrm{Cu}(\mathrm{II})$ and $4.5 \times 10^{-5} \mathrm{~mol} \mathrm{~L}^{-1} \mathrm{DDTC}$, in presence of the surfactant Triton $\mathrm{X}-100$ with concentrations changing from 0 to $0.8 \% \mathrm{~m} / \mathrm{v}$. As can be seen in Figure 3, increasing the Triton X-100 concentration, the sorption efficiency of $\mathrm{Cu}$ (II)-DDTC by PUF diminishes. The results verified in this experiment support that the mechanism involved on the sorption of $\mathrm{Cu}$ (II)-DDTC by PUF is an ether-like solvent extraction.

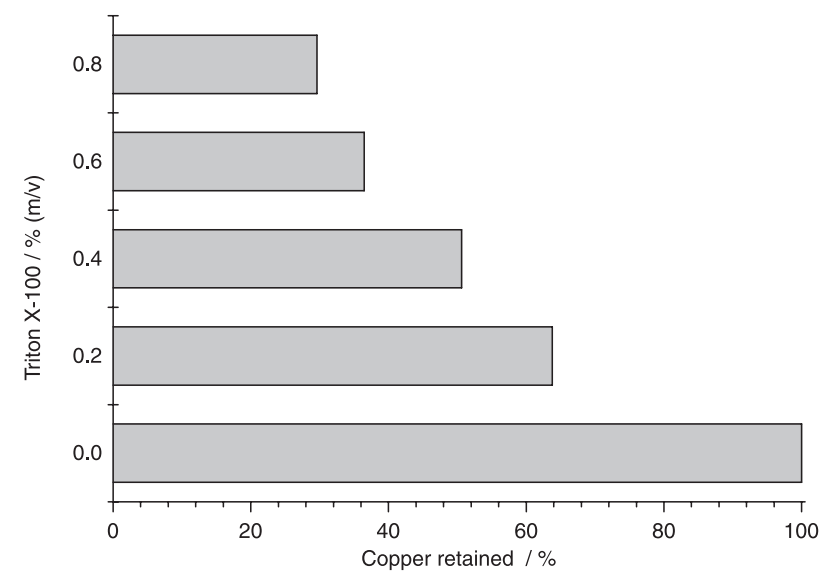

Figure 3. Influence of Triton $\mathrm{X}-100$ concentration (surfactant agent) on $\mathrm{Cu}$ (II) metal ion retention. PUF mass $=10 \mathrm{mg} ; \mathrm{pH}=6.8$; [DDTC] $=4.5 \times 10^{-5} \mathrm{~mol} \mathrm{~L}^{-1} ;[\mathrm{Cu}(\mathrm{II})]=40 \mu \mathrm{g} \mathrm{L}^{-1}$; Shaking time $=1 \mathrm{~h}$.

\section{Kinetic characterization of the extraction process}

The kinetics of the sorption of $\mathrm{Cu}$ (II)-DDTC complex onto PUF was investigated agitating $25 \mathrm{~mL}$ of solution containing $80 \mathrm{mg} \mathrm{L}^{-1} \mathrm{Cu}(\mathrm{II}), 1.78 \times 10^{-4} \mathrm{~mol} \mathrm{~L}^{-1}$ DDTC and pH 6.8 with $10 \mathrm{mg}$ of PUF in the range of $0.5-120 \mathrm{~min}$. The sorption percentage was attained by determining the amount of copper remained in the solution. In this experiment, it was verified that the sorption equilibrium was attained near to $40 \mathrm{~min}$ (Figure 4).

It is well recognized that the characteristic of sorbent surface is a critical factor that affect the sorption rate parameters and that film resistance plays an important role in the overall transport of the solute. So that, to quantify

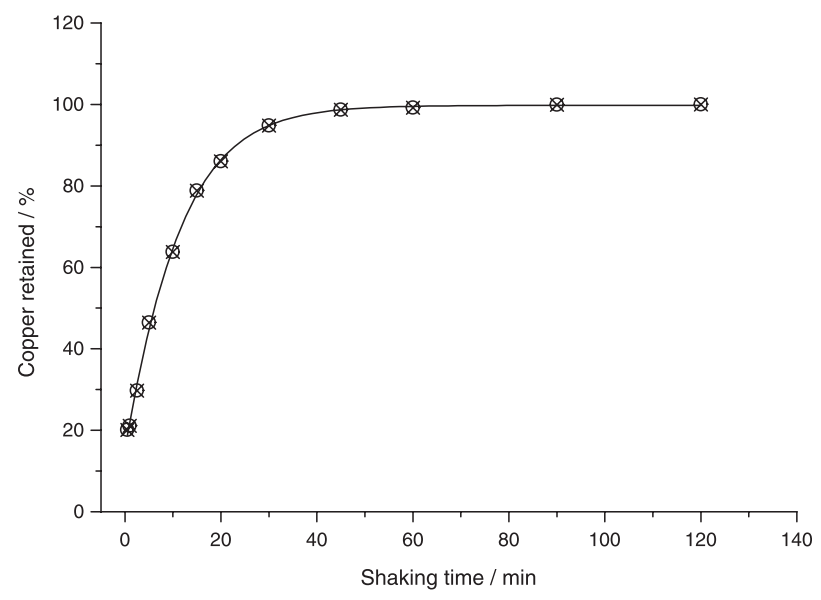

Figure 4. Effect of the shaking time on the retention of $\mathrm{Cu}$ (II) $\left(80 \mu \mathrm{g} \mathrm{L}^{-1}\right)$. PUF mass $=10 \mathrm{mg} ;[$ DDTC $]=1.78 \times 10^{-4} \mathrm{~mol} \mathrm{~L}^{-1}$; $\mathrm{pH}=6.8$.

the changes in the sorption of $\mathrm{Cu}$ (II)-DDTC with time, an appropriate kinetic model is required. For this purpose three models were tested. First of all, the first order Lagergren equation was applied to sorption kinetics: ${ }^{23}$

$\log \left(q_{e}-q_{t}\right)=\log q_{e}-\frac{k t}{2.303}$

where $q_{e}$ is the concentration of $\mathrm{Cu}$ (II)-DDTC complex sorbed at equilibrium ( $\left.\mathrm{mol} \mathrm{g}^{-1}\right), \mathrm{q}_{\mathrm{t}}$ is the concentration of $\mathrm{Cu}$-DDTC complex sorbed at time $\mathrm{t}\left(\mathrm{mol} \mathrm{g}^{-1}\right)$ and $\mathrm{k}$ is the overall rate constant.

It was observed that the sorption of $\mathrm{Cu}$ (II)-DDTC complex followed the Lagergren equation over the entire range of shaking time explored. From the slope of this plot, shown in Figure 5, the value of first-order rate constant $k$ was evaluated to be $7.94 \times 10^{-2} \mathrm{~min}^{-1}$.

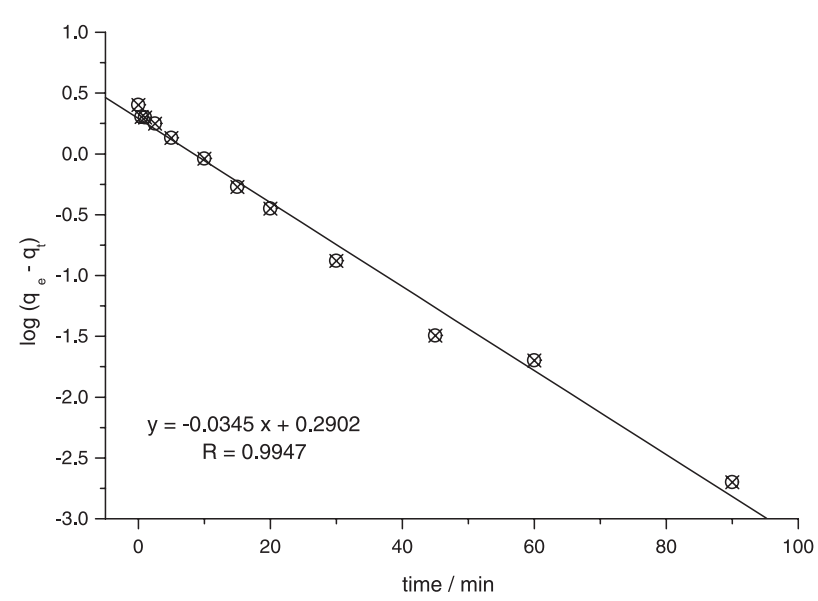

Figure 5. Lagergren plot for the kinetic modeling of $\mathrm{Cu}(\mathrm{II})$-DDTC complex sorption onto PUF. 
The kinetics of sorption of $\mathrm{Cu}(\mathrm{II})$-DDTC onto PUF was also evaluated by applying the Morris-Weber equation: ${ }^{16,24}$

$q_{t}=K_{d} \sqrt{t}$

where $\mathrm{q}_{\mathrm{t}}\left(\mathrm{mol} \mathrm{g}^{-1}\right)$ is the amount of $\mathrm{Cu}$ (II)-DDTC complex sorbed at times $t$ (minutes) and $\mathrm{K}_{\mathrm{d}}$ is the rate constant of intraparticle transport $\left(\mathrm{mol} \mathrm{g}^{-1} \mathrm{~min}^{-1 / 2}\right)$. According to this model, plotting a graphic of $\mathrm{q}_{\mathrm{t}}$ versus $\sqrt{\mathrm{t}}$, if a straight line passing through the origin is obtained, it can be assumed that the involved mechanism is a diffusion of the species. In this case the slope of the linear plot is the rate constant of intraparticle transport $\left(\mathrm{K}_{\mathrm{d}}\right)$. As can be seen in Figure 6a, for times up to $20 \mathrm{~min}$, the Morris-Weber relationship holds good, only deviating for higher agitation times. From the slope of the linear plot obtained in the initial stage, Figure $6 \mathrm{~b}$, the value of $\mathrm{K}_{\mathrm{d}}$ was estimated to be $0.05 \mu \mathrm{mol} \mathrm{g}^{-1} \mathrm{~min}^{-1 / 2}$.

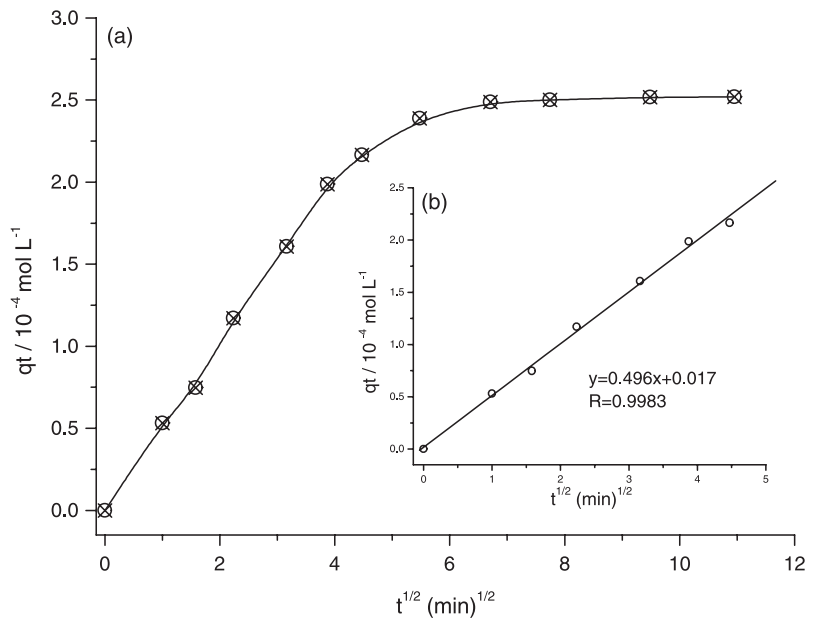

Figure 6. Morris-Weber plot for the kinetic modeling of $\mathrm{Cu}(\mathrm{II})$ DDTC complex sorption onto PUF. (a) Plot for overall range time tested and (b) Linear plot for the first 20 min shaking time.

A third model, presented by Reichenberg, ${ }^{25}$ was tested on the kinetic sorption of $\mathrm{Cu}(\mathrm{II})$-DDTC on PUF:

$F=\left(1-\frac{6}{\pi^{2}}\right) e^{-B t}$

where $\mathrm{F}$ is the ratio $\mathrm{q}_{\mathrm{t}} / \mathrm{q}_{\mathrm{e}}$ and $\mathrm{Bt}$ is a $\mathrm{F}$ function and can be calculated from each value of $\mathrm{F}$, such as:

$\mathrm{Bt}=-0.4977-\ln (1-\mathrm{F})$

As can be seen in Figure 7, plotting Bt versus t, a straight line passing through the origin is obtained and, according to this model it characterizes the rate-determining mechanism being a diffusion across the liquid film surrounding the foam particle.

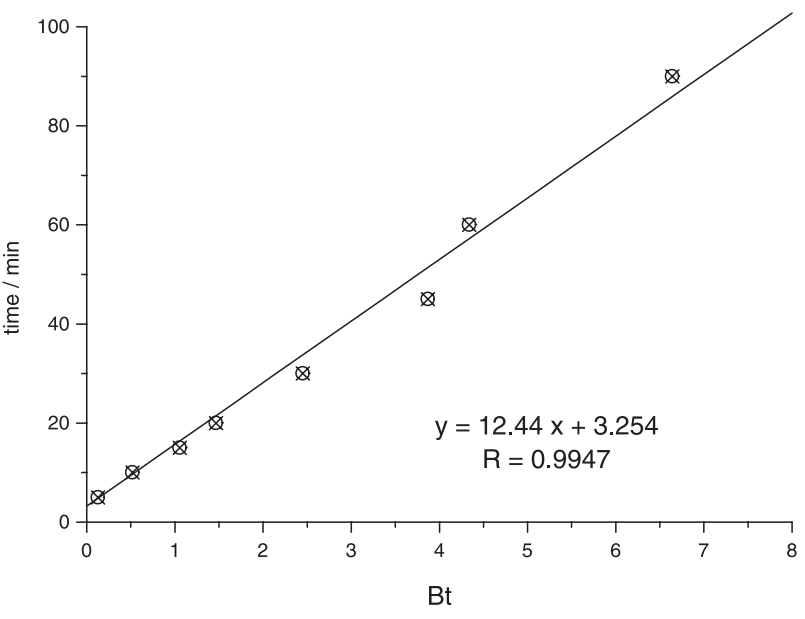

Figure 7. Reichenberg plot for the kinetic modeling of $\mathrm{Cu}(\mathrm{II})$ DDTC extraction by PUF.

\section{Presence of metallic concomitants}

It is well recognized that the formation of a metal complex can be affected by the presence of another ion, which reacts with the complexing agent or metallic cation. Therefore, in order to verify the effect caused by the presence of metallic ions such as $\mathrm{Zn}$ (II), $\mathrm{Fe}$ (III), $\mathrm{Pb}$ (II), Ni(II), $\mathrm{Co}$ (II) and $\mathrm{Cd}(\mathrm{II})$ on the $\mathrm{Cu}$ (II)-DDTC sorption by PUF, known concentrations of the possible interferents were added in aliquots of $25 \mathrm{~mL}$ of solution containing $40 \mu \mathrm{g} \mathrm{L}^{-1} \mathrm{Cu}(\mathrm{II}), 4.5 \times 10^{-5} \mathrm{~mol} \mathrm{~L}^{-1}$ DDTC and $\mathrm{pH} 6.8$. As previously done, the final solution was agitated with $10 \mathrm{mg}$ of PUF during 1 hour and the $\mathrm{Cu}$ (II) remained in solution was determined by ETAAS. The results are summarized in Table 3.

Table 3. Effect of foreign ions on the sorption of $\mathrm{Cu}(\mathrm{II})$-DDTC complex by PUF

\begin{tabular}{ccc}
\hline Foreign ions & Ion/ $\mathrm{Cu}^{2+}$ & $\mathrm{Cu}$ retained $(\%)$ \\
\hline $\mathrm{Pb}(\mathrm{II})$ & 25 & 99.7 \\
& 50 & 99.2 \\
$\mathrm{Fe}(\mathrm{III})$ & 10 & 99.8 \\
& 25 & 85.8 \\
$\mathrm{Zn}$ (II) & 25 & 94.4 \\
& 50 & 82.7 \\
$\mathrm{Ni}$ (II) & 25 & 98.2 \\
& 50 & 93.9 \\
$\mathrm{Cd}$ (II) & 25 & 93.9 \\
& 50 & 92.4 \\
$\mathrm{Co}(\mathrm{II})$ & 25 & 91.6 \\
& 50 & 98.3 \\
\hline
\end{tabular}

As can be seen in the results, the most of cations tested did not affect the $\mathrm{Cu}$ (II)-DDTC sorption even when added in concentrations 50 fold higher than $\mathrm{Cu}$ (II). The noticeable 
exceptions were Fe(III) (25 fold) and Zn(II) (50 fold). As explained above, these concomitants diminished the sorption of $\mathrm{Cu}(\mathrm{II})$ because they react with DDTC in the established conditions.

\section{Conclusions}

The polyurethane foam solid phase presented high capacity and selectivity (in presence of EDTA) to extract $\mathrm{Cu}$ (II) ions complexed by DDTC, thus opening new possibilities to preconcentrate and/or separate this cation in aqueous medium. Also, taking into account the hydrophobic characteristic of the complex, it was possible to conclude that a solvent extraction mechanism controls the whole sorption process with the foam acting as a similar way of a non-polar organic solvent. This hypothesis is highlighted when a surfactant agent (such as Triton X100) was added to the extraction medium, which strongly decreased the amount of $\mathrm{Cu}(\mathrm{II})-\mathrm{DDTC}$ retained by foam, thus indicating that in a medium where the complex is more soluble, the sorption is diminished due to the lower affinity between the solid phase and $\mathrm{Cu}(\mathrm{II})$-DDTC. This process is usually observed when a solvent extraction mechanism is involved and can be considered as a reverse salting-out effect.

Kinetically, the sorption process was featured by applying three different models. Testing the system for Morris-Weber, Lagergren and Reichenberg equations, it was possible to determine a first order kinetic constant equal to $7.94 \times 10^{-2} \mathrm{~min}^{-1}$. Also, these results indicated that a film diffusion mechanism was a rate-determining step of the whole extraction process.

Considering the high sorption capacity of PUF, the determination of copper remained in the solution after $\mathrm{Cu}$ (II)-DDTC retention by foam must be carried out by employing a sensitive analytical technique. In the present situation, ETAAS showed adequate characteristics to accomplish all sorption studies, making possible copper trace determinations.

\section{Acknowledgements}

The authors are grateful to CNPq (Conselho Nacional de Desenvolvimento Científico e Tecnológico), CAPES (Coordenação de Aperfeiçoamento de Pessoal de Nível Superior) and FAPERJ (Fundação de Amparo à Pesquisa do Estado do Rio de Janeiro) for the grants and fellowships, and for financial support.

\section{References}

1. Quek, S.Y.; Wase, D.A.J.; Forster, C.F.; Water SA 1998, 24, 251.

2. Singh, D.; Rawat, N.S.; Ind. J. Chem. Technol. 1997, 4, 39.

3. Wase, D.A.J.; Forster, C.F.; Biosorbents for Metal Ions, Taylor and Francis: London, 1997.

4. Tunçeli, A.; Tucker, A. R.; Talanta 2000, 51, 889.

5. Hiraide, M.; Iwasawa, J.; Kawaguchi, H.; Talanta 1997, 44, 231.

6. Bowen, H.J.M.; J. Chem. Soc. 1970, 1082.

7. El-Shahawi, M.S.; Aldhaheri, S.M.; Anal. Chim. Acta 1996, 320, 277.

8. Schumack, L.; Chow, A.; Talanta 1987, 34, 957.

9. Cassella, R.J.; Garrigues, S.; Santelli, R.E.; de la Guardia, M.; Analyst 2000, 125, 257.

10. Cassella, R.J.; Santelli, R.E.; Branco, A.G.; Lemos, V.A.; Ferreira, S.L.C.; de Carvalho, M.S.; Analyst 1999, 124, 805.

11. de Jesus, D.S.; Cassella, R.J.; Ferreira, S.L.C.; Costa, A.C.S.; de Carvalho, M.S.; Santelli, R.E.; Anal. Chim. Acta 1998, 366, 263.

12. Maloney, M.P.; Moody, G.J.; Thomas, J.D.R.; Analyst 1980, 105, 1087.

13. Cassella, R.J.; Salim, V.A.; Jesuíno, L.S.; Santelli, R.E.; Ferreira, S.L.C.; de Carvalho, M.S.; Talanta 2001, 54, 61.

14. Ferreira, S.L.C.; de Jesus, D.S.; Cassella, R.J.; Costa, A.C.S.; de Carvalho, M.S.; Santelli, R.E.; Anal. Chim. Acta 1999, 378, 287.

15. Braun, T.; Navratil, J.D.; Farag, A.B.; Polyurethane Foam Sorbents in Separation Science, CRC Press Inc.: Boca Raton, 1985 .

16. Hasany, S.M.; Saeed, M.; Ahmed, M.; Sep. Sci. Technol. 2000, $35,379$.

17. Al-Bazi, S.J.; Chow, A.; Talanta 1983, 30, 487.

18. El-Shahawi, M.S.; Kiwan, A.M.; Al-Daheri, S.M.; Saleh, M.H.; Talanta 1995, 42, 1471.

19. Sandell, E.B.; Colorimetric Determination of Traces of Metals, $3^{\text {rd }}$ ed., Interscience Publishers: New York, 1959.

20. Braun, T.; Farag, A.B.; Anal. Chim. Acta 1974, 71, 133.

21. Braun, T.; Farag, A.B.; Anal. Chim. Acta 1975, 76, 133.

22. Valente, I.; Bowen, H.J.M.; Analyst 1977, 102, 842.

23. Gaid, A.; Kaoua, F.; Mederres, N.; Khodjsa, M.; Water SA 1994, 20, 273.

24. Hasany, S.M.; Saeed, M.M.; Ahmed, M.; Talanta 2001, 54, 89.

25. Reichenberg, D.; J. Am. Chem Soc. 1953, 75, 589.

Received: February 20, 2002

Published on the web: July 16, 2003 